\title{
Integration of Task-Based Approaches in a TESOL Course
}

\author{
Chin-Wen Chien ${ }^{1}$ \\ ${ }^{1}$ Department of English Instruction, National Hsinchu University of Education, Taiwan \\ Correspondence: Chin-Wen Chien, Department of English Instruction, National Hsinchu University of \\ Education, Hsinchu 300, Taiwan. Tel: 886-3-521-3132 ext.6712. E-mail: chinwenc@ms24.hinet.net
}

$\begin{array}{ll}\text { Received: May 26, } 2014 & \text { Accepted: July 14, } 2014 \quad \text { Online Published: August 14, } 2014 \\ \text { doi:10.5539/elt.v7n9p36 } & \text { URL: http://dx.doi.org/10.5539/elt.v7n9p36 }\end{array}$

\begin{abstract}
Under task-based language teaching (TBLT), language learners engage in purposeful, problem-oriented, and outcome-driven tasks that are comparable to real-world activities. This qualitative case study discusses the integration of a task-based approach into a TESOL course in a language teacher education program in Taiwan with regard to 39 participants' attitude and learning in a northern city in Taiwan. The major data in this study included participants' projects, class observations and class PowerPoint slides, and class evaluations. The study has the following findings. First, a total of 20 tasks were designed in order to help participants be familiar with TESOL issues. Second, participants held positive attitudes toward the integration of tasks into this TESOL course because they felt that they learned TESOL issues. They regarded Catherine as a role model in modeling the task-based approach into the class and she clearly explained how each task should be carried out and completed. Moreover, she scaffolded participants while they had problems. Finally, participants learned TESOL issues, different types of task, and research methods through completing the tasks, group discussion, classmates' sharing, reading texts and references, and the instructor's scaffolding.
\end{abstract}

Keywords: congruent teaching, scaffold, task, task-based approach, TESOL issues

\section{Introduction}

Under task-based language teaching (TBLT), language learners engage in purposeful, problem-oriented, and outcome-driven tasks that are comparable to real-world activities. According to Adams (2009), task-based language teaching has been practiced at the nexus of theories including input processing (Van Patten, 1996), information process (Levelt, 1989), the interactionist approach (Mackey \& Gass, 2006), and neo-Vogotskian socio-cultural theory (Lantolf, 2000a). By doing so, language teachers encourage meaningful communication and provide a context for learners to study the language (Willis, 1996). Task-based or task-supported teaching has been advocated as a means of promoting language learning in language classrooms in different settings (Branden, Gorp, \& Verhelst, 2007; Eckerth \& Siekmann, 2008; Samuda \& Bygate, 2008; Van den Branden, 2006) and has become prominent a research focus in the last decade (Adams, 2009; Ellis, 2003). However, when implementing TBLT in language classrooms, language teachers face some difficulties and uncertainties in terms of classroom managerial and disciplinary issues, learners' language proficiency, or teachers' competence and theoretical knowledge (Carless, 2003; Littlewood, 2004; Plews \& Zhao, 2010).

Successfully implementing TBLT or a task-based approach into language classrooms depends on English teachers' competence, expertise, and attitudes. In order to effectively turn the theoretical knowledge base of TBLT or a task-based approach into effective practice, language teachers are encouraged to understand better the principles and procedures of TBLT and to develop awareness of their own perceptions and attitudes (Karavas-Doukas, 1996; Plews \& Zhao, 2010). Current studies on TBLT or a task-based approach focus mostly on language classrooms, but less on language teacher education programs. These programs must prepare pre-service and in-service teachers with the skills and knowledge needed to make appropriate lesson adaptations, accommodations, and modifications (Plews \& Zhao, 2010). This study discusses the integration of a task-based approach into a TESOL course in a language teacher education program in Taiwan with regard to participants' attitude and learning. The following questions were discussed. First, what types of tasks were designed and identified in the course? Second, what was the participants' attitude toward the integration of a task-based approach into the TESOL seminar course? Did participants perceive the instructor as a role model regarding the task-based approach? Third, what did participants learn about TESOL issues from these tasks? Suggestions on designing and implementing tasks for language teacher education programs are provided. 


\section{Literature Review}

The literature review in this study focuses on a task-based approach and congruent teaching.

\subsection{Task-Based Approach}

Hayes (1995) suggests that the training for language teachers should be task-based. Skehan (1998) defines tasks based on the following four criteria: meaning is primary, it works toward a goal, it is outcome-evaluated, and it is related to the world outside the classroom. According to Clark, Scarino, and Brownell (1994), a task includes the following five components: (1) a purpose or underlying real-life justification for doing the task that involves more than simply displaying knowledge or practicing skills; (2) a context in which the task takes place that may be real, simulated, or imaginary; (3) a process of thinking and doing; (4) a product or the result of thinking and doing; and (5) a framework of knowledge and skills.

Under task-based language teaching, tasks are defined differently from a target task or pedagogical task as shown in Table 1. In this article, a task is defined as "a classroom activity with clearly specified objectives that promote learners' desires to learn. Moreover, during the task, learners are provided with opportunities for meaningful language use in purposeful interaction."

Table 1. Definitions of tasks

\begin{tabular}{|c|c|c|}
\hline Scholars & Terms & Definitions \\
\hline $\begin{array}{l}\text { Long } \\
(1985, \\
\text { p. 89) }\end{array}$ & a target task & $\begin{array}{l}\text { A piece of work undertaken for oneself or for others, freely or for some reward. } \\
\text { Thus examples of tasks include painting a fence, dressing a child, filling out a form, } \\
\text { buying a pair of shoes, making an airline reservation, borrowing a library book, } \\
\text { taking a driving test, typing a letter, weighting a patient, sorting letters, making a } \\
\text { hotel reservation, writing a cheque, finding a street destination and helping someone } \\
\text { across a road. In other words, by task is meant the hundred and one things people do } \\
\text { in every day life, at work, at play, and in between. }\end{array}$ \\
\hline
\end{tabular}

Richards, pedagogical An activity or action which is carried out as the result of processing or Platt, \& task understanding language. For example, drawing a map while listening to a tape, Weber listening to an instruction and performing a command may be referred to as tasks.

$(1986$, p. 289)

Breen pedagogical (1987, task p. 23)

Ellis pedagogical (2003, task p. 16)

Nunan $(2004$, pedagogical p. 4) Tasks may or may not involve the production of language. A task usually requires the teacher to specify what will be regarded as successful completion of the task. The use of a variety of different kinds of tasks in language teaching is said to make language teaching more communicative. Since it provides a purpose for a classroom activity which goes beyond the practice of language for its own sake.

Any structured language learning endeavor which has a particular objective, appropriate content, a specified working procedure, and a range of outcomes for those who undertake the task. Task is therefore assumed to refer to a range of workplans which have the overall purposes of facilitating language learning-from the simple and brief exercise type, to more complex and lengthy activities such as group problem-solving or simulations and decision-making.

A task is a workplan that requires learners to process language pragmatically in order to achieve an outcome that can be evaluated in terms of whether the correct or appropriate propositional content has been conveyed. To this end, it requires them to give primary attention to meaning and to make use of their own linguistic resources, although the design of the task may predispose them to choose particular forms. A task is intended to result in language use that bears a resemblance, direct or indirect to the way language is used in the real world. Like other language activities, a task can engage productive or receptive, and oral or written skills and also various cognitive processes.

A pedagogical task is a piece of classroom work that involves learners in comprehending, manipulating, producing or interacting in the target language while their attention is focused on mobilizing their grammatical knowledge in order to express meaning, and in which the intention is to convey meaning rather than to manipulate form. The tasks should also have a sense of completeness, being able to stand alone as a communicative act in its own right with a beginning, a middle, and an end. 
Many different types of tasks have been implemented in language classrooms including problem-solving, decision-making, opinion-gap or opinion exchange, information gap, sharing personal experiences, attitudes or feelings, comparisons and contrasts, matching, sorting, narrative, structured or semi-structured dialogues, role-plays, simulations, discussions, debate, etc. (Oxford, 2006).

Teachers have to take several factors into consideration when they design and implement tasks including the amount of time allotted to the task, teachers' role and characteristics, learners' role and characteristics, task complexity, and difficulties of the tasks (Oxford, 2006). Learners at the beginning level may feel challenged if they have to complete the task at a certain speed and within a certain amount of time (Oxford, 2006; Skehan, 1998). Honeyfield (1993) identifies several factors that influence task difficulty including procedures to derive output from input. Input text, required output, topic knowledge, text handling, conversation strategies, amount and type of help given, roles and characteristics of teachers and learners, and time allowed. Skehan (1998) also points out factors related to task difficulty such as linguistic complexity, cognitive complexity, and communicative stress.

Cameroon (1997) argues that tasks can function as a unit in teacher development at two levels as follows:

The task can capture aspects of classroom reality at a central level of description, enabling generalization upwards into lesson and course planning, and more detailed analysis downwards into language learning processes, and their interrelation with teaching.... Secondly, the training itself can be task-based, making use of similar stages and components as classroom tasks, and thus modeling task-based methodology and thinking for trainees. (p. 345)

Al-Wreikat and Abudullah's (2011) study evaluated English as a foreign language (EFL) Jordanian teachers' opinions on in-service training and concluded that teachers asked for clarification of reasons for using the task-based approach. Jackson (2012) used fifteen Japanese novice language teachers' retrospective comments, classroom discourse, and survey results to examine the effectiveness of the task-based teacher education approach. Participants gained and shared knowledge relating to teaching practice through classroom tasks. Jackson suggested that task-based teacher training can be adopted to support curricular innovation to enhance language education in the Japanese EFL setting.

Many studies conducted on task-based language teaching and learning mainly focus on classroom practice both in EFL (English as a foreign language) (Carless, 2003; Chaung, 2010; Gatbonton \& Gu, 1994; Keon \& Hahn, 2006; Littlewood, 2004; McDonough \& Chaikitmongkol, 2007, Van den Branden, 2009) or ESL (English as a second language) classroom settings (Plews \& Zhao, 2010). Only a few studies focus on the task-based approaches for teacher education programs or professional development among language teachers (Al-Wreikat \& Abudullah, 2011; Jackson, 2012; Moser, Harris, \& Carle, 2012) and mathematics teachers (Swain, 2007). This study focuses on the teacher trainer's congruent teaching of a task-based approach in a TESOL course for pre-service teachers in Taiwan. It aims to analyze pre-service teachers' perspectives and attitude toward the integration of a task-based approach into a TESOL course.

\subsection{Congruent Teaching in Teacher Education}

For congruent teaching, teacher educators model the anticipated education practice, explain the choices they make (meta-commentary), and link the choices to relevant theories (Swennen, Lunenberg, \& Korthagen, 2008). Swennen et al. (2008) coined congruent teaching as "preach what you teach."

Ruys, Defruyt, Rots, and Aelterman's (2013) study examined whether, how, and to what extent a teacher educator provided differentiated instruction in a congruent way in a master's degree in Educational Science in a Flemish university. The observed teacher educator demonstrated limited forms of differentiated instruction, owing to the lack of meta-commentary. Giving meta-commentary is a crucial aspect of the pedagogical behavior of teacher educators. Provision of meta-commentary is not evident among teacher educators (Bullough, 1997; Ruys et al., 2013). The researchers concluded that the observed teacher educator was not considered as a role model on the subject of differentiated instruction in the view of student teachers. Swennen, Korthagen, and Lunenberg (2004) argue, "Modeling is important, but it is not sufficient in itself to speak of congruent training nor is it sufficient to achieve the desired improvements in the educational training" (p. 18). Therefore, giving meta-commentary on the modeling behavior is necessary in order to facilitate the translation of the modeling behavior to the student teachers' practices (Lunenberg, Korthagen, \& Swennen, 2007).

Ruys et al. (2013) suggested, "An impetus for further reflection on the possibilities of making teacher educators more familiar with and competent in providing meta-commentary" (p. 102). Swennen et al.'s (2008) study discusses the influence of workshops on congruent teachers on three teacher educators. They found that through 
the workshop, the teacher educators' ability to link their own teaching to theory had improved. Therefore, Swennen et al. (2008) recommended the following:

Teacher educators need to have more than theoretical knowledge and skills at their disposal, as well as the ability to link this expertise to their own practices and the practices of their student teachers: they need to learn the professional language, not only to enhance the level of congruent teaching, but also in order to learn from the expertise of colleagues, to reflect on their own teaching and to develop as teacher educators. (p. 541)

Only a limited number of studies focus on the congruent teaching and meta-commentary among teacher educators (Ruys et al., 2013; Swennen et al., 2008). This study investigates a language teacher educator's congruent teaching of a task-based approach in a TESOL course in a language teacher education program in Taiwan.

\section{Method}

This is a qualitative case study. This study discussed the integration of task-based approaches into a TESOL seminar course in a language teacher education program in a northern city in Taiwan. A case study is an in-depth description and analysis of a bounded system (Merriam, 2009). Yin (2008) defined a case study as "an empirical inquiry that investigates a contemporary phenomenon within its real-life context" (p. 18). This case is one TESOL seminar class and the data of analysis is the students' learning through tasks.

\subsection{Participants}

Thirty nine participants partook in this study enrolled in a TESOL seminar course, part of a language teacher education program in a northern city in Taiwan. The participants included 32 females and 7 males with an average of 20.6 years. Two participants were from the Department of Education including one graduate student with a major in Education. The rest of the participants were seniors with a major in English Instruction. The class met for three hours each week during the period of the study.

This course was designed to introduce current issues in TESOL and provide a review of some important concepts in TESOL, including principles and techniques in language teaching, and offer guidance to research into linguistics topics. During the 2013 fall semester, three instructors taught this class and each taught for six weeks. This study focused on the second instructor (Catherine, pseudonym) who integrated task-based approaches into this class.

\subsection{Data Collection}

The study was conducted over six weeks, from mid-October to the end of November 2013.The major data in this study included: (1) participants' projects, (2) class observations and class PowerPoint slides, and (3) class evaluations.

Participants were asked to complete 20 tasks. Documents enable a researcher to obtain the language and words of informants. Documents can be an unobtrusive source of information and can be accessed at a time convenient to researchers (Creswell, 2009). The researcher made copies and analyzed participants' completed tasks in order to find out participants' learning on TESOL issues.

Observational notes detail what the researcher actually saw (Chatman, 1992). The researcher observed participants' completion of the tasks and took the field notes. Such field notes provided the researcher with the full picture of participants' learning related to TESOL issues.

At the end of the fifth day of the class, participants were asked to answer nine open-ended questions on the class evaluation sheet as in Appendix A. These nine questions were designed to ascertain the participants' opinions, attitudes, and learning concerning the integration task-based approach in this TESOL course.

\subsection{Data Analysis}

When the data were collected, observations, class PowerPoint files, and class evaluations were transcribed into raw field notes. The data was coded in the following three stages. First, the researcher read through all the notes and marked the data by a code (e.g. task type, adjectives for emotions, etc.). Secondly, while reading through these codes, the researcher labeled tentative categories (e.g. attitude, task, etc.). Finally, the data were sorted on the basis of their relevance into topics that reflect the research questions, as in Figure 1. A set of codes for thematic analysis was constructed that captures the meaning expressed by the data (Flick, 1998). 


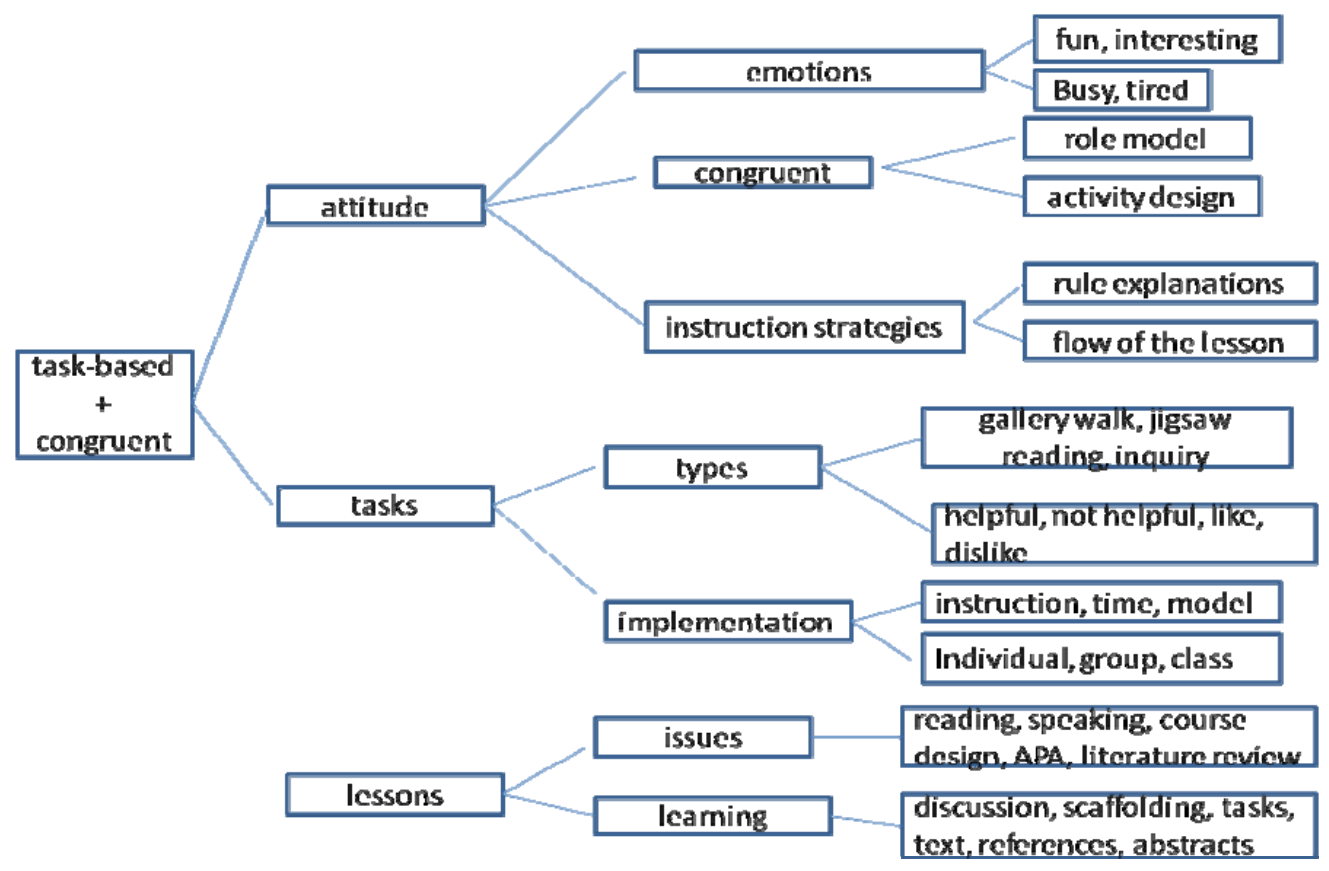

Figure 1. Data analysis

Triangulation entails the use of more than one method or source of data in a research endeavor (Boeije, 2010; Shank, 2006). In this study triangulating multiple sources of data (e.g. documents, observation notes, class evaluations) could add texture, depth, and multiple insights to an analysis and could enhance the trustworthiness or credibility of the results.

\section{Results}

Based on the above data analysis, the findings were discussed in terms of attitude toward tasks, types of task, implementations of tasks, and lessons learned.

\subsection{Attitude toward Tasks}

Almost all participants had a positive attitude toward the tasks $(n=36,90 \%)$. The most popular responses were "learned a lot" $(\mathrm{n}=27,69.2 \%)$ and "fun and interesting" $(\mathrm{n}=15,38.4 \%)$. One participant responded that: "Through integrated tasks, we learned a lot from it in different ways and they were all fantastic"; "Different tasks make me understand the paper more and know how to read and write the paper"; "I enjoy trying various types of tasks"; or "I feel interested about doing different tasks."

Other responses included "challenging but great" $(\mathrm{n}=6,15.4 \%)$, "busy" $(\mathrm{n}=5,12.8 \%)$, "cheerful class atmosphere" ( $\mathrm{n}=1,2.5 \%)$, "had interaction with classmates" ( $\mathrm{n}=1,2.5 \%)$. One participant responded, "I think it is busy but it helps me a lot about how to find the issues of teaching or find key points in an essay." Another participant claimed, "I never feel bored in class. I have chances to show myself and interact with others through completing these tasks."

However, in response to "How did you feel about doing different tasks," a number of participants wrote a negative answer such as "tired" $(\mathrm{n}=3,7 \%)$. A male participant complained, "I felt tired but it is worth doing a varieties of tasks." A female participant wrote, "I felt busy. After doing many tasks, sometimes I felt tired and dizzy."

Seven participants claimed that they liked all the tasks. The most popular tasks were "Mind-mapping from Journal Articles and Conference Proceedings" ( $\mathrm{n}=15,38.5 \%)$, followed by "Gallery Walk" $(\mathrm{n}=13,33.3 \%)$ and "Jigsaw Readings" ( $\mathrm{n}=5,12.8 \%)$. With regard to their liking of the task "Mind-mapping from Journal Articles and Conference Proceedings," the majority of the participants wrote ideas similar to "I learned to read the abstracts from journal articles and conference proceedings, searched for the key words, and wrote down and shared my ideas on the poster. I also learned from others' sharing." In terms of their preferences for "Gallery Walk" and "Jigsaw Reading," all participants liked the concept of cooperative learning behind these two tasks and claimed, "I can learn from different concepts from other groups" or "We can work together to understand a 
topic or issue and gain TESOL related knowledge through classmates' explanations."

Of all the 20 tasks, owing to the time constraints, participants regarded their least favorite tasks as "Gallery Walk" ( $n=7,18 \%)$, followed by "Jigsaw Reading" $(n=6,15.4 \%)$ and "Inside and Outside Circles" $(n=6,15.4 \%)$. Participants claimed that they liked the designs and objectives of these tasks; however, they felt under great pressure to share and exchange their information, to jot down the information, and to digest the concepts in the limited time.

\subsection{Types of Tasks}

A total of 20 tasks were designed and implemented in class as shown in Table 2. At the beginning of each lesson in classes 1, 2, and 3, Catherine explained the objectives and designs of these tasks. Below is an example on TESOL issues in reading:

Today we will focus on teaching and learning reading. There are three objectives for today's class. First, by the end of the class, you can explain theories, key concepts, and important scholarships in teaching and learning reading. Second, you can describe related research issues on QAR and station teaching. Finally, you can investigate my research interests and narrow down my research on topics related to reading. Six tasks are designed for you to achieve the goals. First, you will read texts on the textbooks to get a broader picture of reading instruction. Then, I will share my research on reading instruction so you can have a sense of what kind of research can be conducted on reading instruction in our local setting. Next, you will read abstracts from journal articles published in the past five years, so you will know the current research issues on reading. Finally, you will focus on your own research interests on teaching or learning reading.

Table 2. Types of tasks given in this TESOL seminar course

\begin{tabular}{|c|c|c|c|c|}
\hline Class & Class 1 & Class 2 & Class 3 & Class 4 \\
\hline Topics & Reading & speaking & course design & APA \\
\hline \multirow{6}{*}{ Tasks } & Inquiry I & Inquiry II & True or False & Turn and Talk \\
\hline & gallery Walk & jigsaw reading & Inquiry III & $\begin{array}{l}\text { APA Style and } \\
\text { format: reference }\end{array}$ \\
\hline & reflections I & reflections II & $\begin{array}{l}\text { inside and outside } \\
\text { circle }\end{array}$ & $\begin{array}{l}\text { searching for } \\
\text { information }\end{array}$ \\
\hline & $\begin{array}{l}\text { mind-mapping from } \\
\text { journal articles }\end{array}$ & $\begin{array}{l}\text { mind-mapping } \\
\text { from conference } \\
\text { proceedings }\end{array}$ & $\begin{array}{l}\text { mind-mapping } \\
\text { journal articles }\end{array}$ & $\begin{array}{l}\text { APA Style and } \\
\text { format: citations }\end{array}$ \\
\hline & $\begin{array}{l}\text { prioritizing Areas of } \\
\text { Investigation }\end{array}$ & & my research issues & \multirow[t]{2}{*}{$\begin{array}{l}\text { matrix Review of } \\
\text { literature }\end{array}$} \\
\hline & narrowing the focus & & my research questions & \\
\hline
\end{tabular}

On classes 1, 2, and 3, participants were assigned to different texts from the textbooks and completed Inquiry I, II, and III on "reading," "speaking" and "course design." Participants shared their notes with one another through tasks "Gallery Walk," "Jigsaw Reading," and "Inside and Outside Circle." After listening to Catherine's research, participants wrote Reflection I and II. Each participant was given an abstract from journal articles or conference proceedings on issues of reading, speaking, and course design. Each participant wrote key words theories, or issues related to reading, speaking, or course design on the poster presentations. They were called randomly to share their ideas afterwards. Finally, for the task "Prioritizing Areas of Investigation," participants made a list of up to six areas for investigation, explained why they chose these areas, and prioritized them in rank order. With regard to the task "Narrowing the Focus," participants picked one of the areas/topics that they were interested in and saw if they could be more specific about exactly which aspect of the area/topics they wished to investigate, along the lines of the example that has just been given. While participants wrote down any issues related to course design for the task "My Research Issues," participants narrowed down their research interests and wrote down issues, research background, purpose of the study, issues to be discussed, and key words under the task "My Research Questions."

During class 4, for the task "Turn and Talk," participants first watched a video about "What is Literature Review?" They also wrote down the main ideas from the video and shared them with a partner. Catherine used 
the website Purdue Owl to introduce the APA style and format. Participants worked in a group of 4-5 and were given a journal article. Each group used the article to write a reference list, underline the important information, and used that information for writing a citation under the three tasks: "APA Style and format: reference," "searching for information," and "APA Style and format: citations." Finally, Catherine introduced the matrix review of literature and participants made a matrix review of literature on the assigned article and presented the matrix review of literature to the whole class for the task "Matrix Review of Literature."

\subsection{Implementations of Tasks}

Catherine used the PowerPoint slides to explain to participants about how to complete the tasks. After the required time, Catherine randomly called some of the participants to share their ideas. All participants regarded Catherine as a role model in integrating tasks into this class, because participants thought Catherine noticeably legitimized her pedagogical choices. A male participant said, "In the introductory class, Catherine clearly taught us that there are about five to six tasks in each class. I anticipated being involved in different tasks from the first day of the class." A female participant also said, "In Catherine's class, I know there were tasks after tasks. I was proud of myself when I completed one task after another. I was always excited to get a new task."

All participants thought the instructions on completing the tasks were clearly given as "Catherine explained each step clearly. Even if we didn't get it, we could read through the instructions on the PowerPoint again and again," or "I love the learning atmosphere - the instructor was a good helper to keep each of us on the right track of learning." An example of instructions on "Inquiry" is shown in Figures 2 and 3 as below:
Discussion Issues
1. What do we know about the process of second language reading?
2. In what way is reading an interactive process?
3. In what way is reading a purpose process?
4. In what way is reading a critical process?
5. What is the role of extensive reading?
6. How do we establish goals for the reading classroom?
7. What criteria do we use to select reading texts?
8. Can we help students to read critically?
9. How can we encourage extensive reading?

Figure 2. Discussion issues

Inquiry
In a small group, read the assigned section. Complete the chart.
\begin{tabular}{|l|l|l|l|}
\hline Key words & Theories & Important scholars & Inquiries \\
\hline & & & \\
\hline
\end{tabular}

Figure 3. Inquiry

Some of the participants said that sometimes they were not sure about how to complete some of the tasks, because they were new types. They did not feel anxious because they could always ask the instructor for help as follows: "Yes, but if the task is a brand new one or a little bit complex, I spent some time to understand it"; "If we had questions, we asked for help and Catherine gave us further explanations"; "The teacher helped us every time when we had trouble following the instructions"; or "Instructions on completing these tasks were all clearly given and the teacher gave us opportunities to inquire when we had questions."

The majority of the participants preferred to complete the tasks as groups ( $\mathrm{n}=32,82 \%)$. Top reasons for group work were: "They could get different opinions or thoughts from other group members"; "Group work was efficient"; or "Group members helped me have a better comprehension of the information." Only one and two 
participants preferred to complete the task as a whole class and on their own, respectively. Four participants thought they liked both individual and group tasks. Reasons for preferring tasks completed by individual and group were: "Tasks should include both group discussion and individual work so that each student can understand the procedure"; "I prefer to complete the task on my own first and then have a discussion with peers since this way is more efficient and I could receive suggestions from my peers"; and "It depends on the difficulties of the tasks. If it is easy, I want to work on my own. If it's challenging, I prefer to work in groups."

\subsection{Lessons Learned from Tasks}

Participants were divided into groups of four to five, and each group was assigned different topics as in Figure 1. Group members read the assigned texts from the textbook and completed the chart in Figure 2. Table 3 reveals a group's inquiry on question 3 "In what way is reading a purpose process?" Group members wrote down the key words "survey the heading," "connect," "read the text" and "outline." Under Theories and Important Scholars columns, they wrote SCROL procedure and Grant (1993). They came up with two research questions regarding the implementation of SCROL in elementary, junior, and senior high schools in Taiwan.

Table 3. Process-based reading

\begin{tabular}{|c|c|c|c|}
\hline Keywords & Theories & Important scholars & Major Questions \\
\hline $\begin{array}{l}\text { survey the heading } \\
\text { connect } \\
\text { read the text }\end{array}$ & SCROL procedure & Grant (1993) & $\begin{array}{l}\text { 1. Can this SCROL procedure be } \\
\text { implemented for junior high or senior } \\
\text { high students in Taiwan in order to } \\
\text { improve their English reading abilities? }\end{array}$ \\
\hline $\begin{array}{l}\text {. outline } \\
\text {. look back }\end{array}$ & & & $\begin{array}{l}\text { 2. Can this SCROL procedure be } \\
\text { implemented for elementary school } \\
\text { students in Taiwan to improve their } \\
\text { English reading ability with picture books } \\
\text { as teaching materials? }\end{array}$ \\
\hline
\end{tabular}

Each participant read one abstract from journal articles on teaching and learning to read. Each participant wrote down key words or terms from the abstract. Participants were called randomly to explain these key words and the abstract. Figure 4 reveals some of the key words participants wrote, such as "word decoding," "self-regulated strategy development," or "content knowledge."

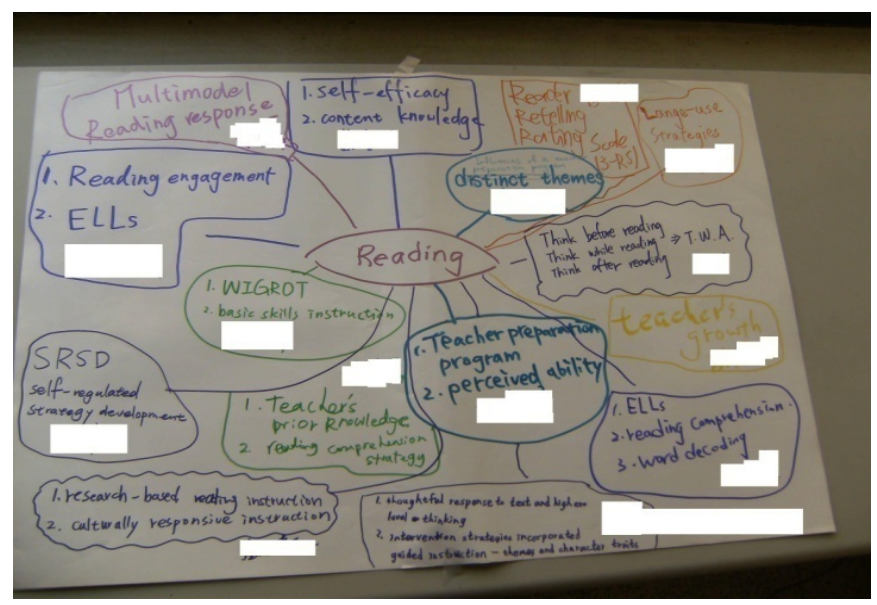

Figure 4. Mind-mapping on journal abstracts on reading

In responding to the question, "How did completing these tasks help you learn about TESOL issues?" the most popular response was "completed one task after another task" $(\mathrm{n}=21)$, followed by "thorough discussion" $(\mathrm{n}=13)$, "from classmates' sharing" $(n=7)$, "the instructor's scaffolding" $(n=6)$ and "read from assigned abstracts, textbooks, or references" $(\mathrm{n}=5)$.

In Episode 1, each participant was given a term such as "structural syllabus," "situational syllabus," "spiral 
syllabus," or "parallel syllabus." Each participant had to find the definition from the assigned reading, write down the page number, and define the term. The instructor explained the task "Inside and Outside Circle." The classroom was too small. Instead of staying in circles, participants were divided into lines. A participant faced another participant and shared his or her terms. After five minutes, participants in one particular line moved five steps to their right. They faced a new participant and shared the term again. In Example 1, participant A tried to explain to participant B what a spiral syllabus is. However, participant B did not understand it, so participant A drew a picture to elaborate her idea. Finally, participant B understood what a spiral syllabus is.

Episode 1: Group Discussion

A: Spiral syllabus came from Brumfit (1980). It includes a series of unfocused tasks that will enable students to use the language they acquired while following a basic syllabus.

B: (She jotted down the words Brumfit, 1980, a series of unfocused tasks, acquired, basic syllabus) Sorry, I did not get it. Could you explain more?

A: (She drew a picture like the spiral on a piece of paper and wrote "graded and sequenced") Well, the syllabus includes a graded and sequence list of linguistic concepts and the teacher follows this syllabus.

B: (She looked at the picture of the spiral and the words "graded and sequenced") (She knocked her head) I got it.

Participants claimed that they not only learned TESOL issues $(\mathrm{n}=27)$, but also different types of tasks $(\mathrm{n}=10)$. Examples of participants' responses were: "I felt great. Different tasks helped me learn TESOL issues and different types of tasks"; "We can learn many issues through tasks, then find some tasks or strategies which are suitable for me"; or "Through different tasks, I have a better understanding of TESOL issues." One male participant claimed, "I will try to include the task-based approach in my presentation or teaching practice in the future."

Fifteen participants claimed that all of the tasks helped them learn TESOL issues. Of all the 20 tasks, "Gallery Walk" was regarded as the most helpful by the participants $(n=10)$ and "Jigsaw Reading" $(n=9)$, followed by "Inquiry" ( $\mathrm{n}=5)$ and "Mind-mapping" $(\mathrm{n}=5)$. In terms of "Gallery Walk," participants' responses included: "I think the gallery walk helped me the most. With the classmates' paragraph and explanations, I can clearly know about the theories of TESOL issues"; "There was a lot of discussions during the gallery walk"; or "Through gallery walk, I can get understandings from other classmates."

However, the least helpful task chosen by the participants was "Mind-mapping" $(n=6)$. Participants felt that they had difficulties in reading and understanding the abstracts from journal articles and conference proceedings within the short period of time owing to their lack of background knowledge of the issues and academic terms in the field of reading, speaking, and course designs. Some of the participants' responses were: "It was not easy for me to gather information in such a short time from mind-mapping"; "I had difficulties in understanding the abstract"; or "I didn't understand the academic terms on the abstracts."

\section{Discussions}

This study discusses the integration of task-based approach into a TESOL course in a language teacher education program. The study has the following findings. First, a total of 20 tasks were designed in order to help participants be familiar with TESOL issues. These tasks included individual tasks (i.e. "My Research Questions"), pair work (i.e. "Turn and Talk"), group work (i.e. "Jigsaw Reading," "Inquiry"), and class project (i.e. gallery walk). Second, participants held positive attitudes toward the integration of tasks into this TESOL course because they felt that they learned TESOL issues. They regarded Catherine as a role model in modeling the task-based approach into the class and she clearly explained how each task should be carried out and completed. Moreover, she scaffolded participants while they had problems. Finally, participants learned TESOL issues, different types of task, and research methods through completing the tasks, group discussion, classmates' sharing, reading texts and references, and the instructor's scaffolding. The following discussions and implications focus on three issues in terms of: integration of task-based approaches into language teacher education programs; congruent teaching and meta-commentary in these programs; and task designs.

\subsection{Socio-Cultural Theories and Task-Based Approaches}

Participants in this study preferred to complete the tasks in groups, rather than on their own or in a whole class, because they felt that they could learn through discussions with their partners, sharing from other classmates, and the teacher trainer's scaffolding. Lewis (1994) proposed that traditional lectures in teacher education programs should be supplemented with tasks because learners can take advantage of the wealth of experience within the 
group. This study is accord with Jackson's (2012) study that 15 Japanese EFL preservice teachers gained and shared knowledge related to teaching practice through classroom tasks.

Vygotsky (1978) argues that social interactions are the basis of an individual's development. An individual's higher mental functions are generated through participating in socially meaningful activities that are mediated by culturally constructed material and conceptual artifacts. Cognitive development proceeds as individuals participate in socially meaningful activities. Therefore, Ellis (2000) claims:

Socio-cultural researchers have focused on how tasks are accomplished by learners and teachers and how the process of accomplishing them might contribute to language acquisition. They view the learners, the teacher and the setting in which they interact as just as important as the task itself. (p. 210)

Vygotsky (1986) views language as the most powerful psychological tool for mediating higher mental functions. At first individuals rely on external material and symbolic artifacts to perform the action. Over time, individuals transform external artifacts into internal representation and eventually they integrate them into their thinking, resulting in self-regulation of the action, and development of the higher mental functions. Self-regulation means that individuals no longer need to rely on the external meditational means because those means have become internalized. As a higher mental function, language is also subject to the mediating effect of tools (Lantolf, 2000a, 2000b). Ellis elaborates the language and the task as: "The learners have to interpret it. This is reflected in the effort that learners put into orientating to the task and establishing their goals for performing it" (p. 209).

\subsection{Congruent Teaching and Meta-Commentary}

Catherine, the instructor in this TESOL course, clearly modeled the designs and implementations of the task-based approach among 39 participants. She also explained the objectives of each class and how and why these tasks could help participants achieve the objectives. According to Swennen et al. (2008), teacher educators seem to agree that to be able to support their student teachers'learning, they themselves should be good models of the kind of teaching they are tryingto promote (p. 531). Catherine, in this study, was a good model of integrating a task-based approach into a course and demonstrated congruent teaching by modeling, explaining the decisions she made, and linking choices of practice to relevant theories. Therefore, Catherine is an expert teacher educator with characteristics claimed by Berry (2009) as follows:

A characteristic of the truly expert teacher educator is one who not only possesses a deep understanding of the hidden or tacit dimensions of teaching, but also, one who can make explicit those deep understandings of practice in ways that encourage articulation by others. (p. 307)

\subsection{Designs, Implementations, and Completion of Tasks}

In this study, factors affect the successful implementation of tasks, including time allotted to task competition, amount of the task in each class, instructions on task completion, the instructor's scaffolding, complexity of the task, and participants' linguistic and cognitive competence. First, participants in this study felt that they were under time pressure when they worked on certain tasks, such as "Inside and Outside Circle," "Gallery Walk," "Jigsaw Reading," or writing a matrix review of literature. One participant wrote, "I was busy in class. For the jigsaw reading, I had to read the assigned text, explain it to my partner, listen to their texts, and jot down the main ideas. There was only a limited amount of time to complete this task. I felt nervous and anxious." The amount of time allotted for the task is a major factor (Honeyfield, 1993; Oxford, 2006; Skehan, 1996). Moreover, although participants felt proud of themselves for completing task after task, participants felt extremely exhausted when there were too many tasks in one class, particularly in class 1 with six tasks. Hence, the number amount of tasks designed and to be completed in each class should be appropriate and adequate to learners' proficiency levels.

Participants regarded as clear the instructions given to complete the tasks. Some of the participants occasionally were not sure about how to complete them, but they claimed that they could rely on the instructor's PowerPoint slides, her reiteration and scaffolding. Participants in this study felt challenged when they had to perform some new tasks, such as the matrix review of literature, or inside or outside circles. Their insufficient linguistic and academic competence in reading journal articles and abstracts hindered their comprehension of the texts and completion the tasks. Hence, according to Oxford (2006),

Learners' familiarity with the material, the topic, or the language properties mitigates some of the difficulty even when the linguistic material is complex. The difficulty is also affected by the number of language skills (reading, writing, speaking, and listening) and subskills required to do the task. (p. 104)

Therefore, when integrating tasks into language classrooms or language teacher education programs, teacher trainers need to take the following factors into consideration: learners' academic and linguistic competence, 
trainers' clear instructions and scaffolding, the amount of time and tasks, and the complexity of the tasks.

\section{Conclusions}

This study discusses the integration of a task-based approach into a TESOL course in a language teacher education program in Taiwan in regards to participants' attitude and learning. Participants held positive attitudes toward the integration of the task-based approach into a TESOL course and regarded the teacher trainer as the role model in demonstrating and elaborating the principles of the task-based approach. This study also identified the factors that influence the implementation of task-based approaches in a language teacher education program. From the perspective of language teacher educators, this empirical study presents a framework for designing, modeling, and implementing a task-based approach in teacher training within pre-service and in-service language teacher education. From a research prospective, this study also moved beyond studying the task-based language learning and teaching among language learners in EFL or ESL classrooms, by focusing on participants in a language teacher education program in an EFL context. Moreover, the findings of this study shed light on the importance of language teacher trainers' congruent teaching and meta-commentary among teacher trainees.

Ogilvie and Dunn (2010) suggest that teacher education programs have the potential to promote innovation in education practices. Student teachers in Ogilvie and Dunn's study utilized task-based language teaching in their practicum. This study focuses only on 39 participants' perspectives and attitudes toward a teacher trainer's congruent teaching on a task-based approach in a TESOL course in a language teacher education program in Taiwan. A further study can focuses on these 39 participants' utilization of a task-based approach in their practicum or future classroom practice to examine if factors such as cultural norms in education and the lack of support for student teachers in Ogilvie and Dunn's (2010) study influence the effective utilization in Taiwanese elementary school English classrooms.

\section{References}

Adams, R. (2009). Recent publications on task-based language teaching: A review. International Journal of Applied Linguistics, 19(3), 339-355. http://dx.doi.org/10.1111/j.1473-4192.2009.00239.x

Al-Wreikat, Y. A. A. S., \& Abdullah, M. K. K. B. (2011). Effectiveness of teaching approaches of in-service training courses for EFL teachers in Jordanian schools. English Language Teaching, 4(1), 190-196. Retrieved from http://www.ccsenet.org/journal/index.php/elt/article/viewFile/9681/6930

Berry, A. (2009). Professional self-understanding as expertise in teaching about teaching. Teachers and Teaching: Theory and Practice, 15(2), 305-318. http://dx.doi.org/10.1080/13540600902875365

Blaikie, N. (2000). Designing social research. Cambridge, UK: Polity Press.

Bloor, M., \& Wood, F. (2006). Keywords in qualitative methods. Thousand Oaks, CA: Sage.

Branden, K. V. D., Gorp, K. V., \& Verhelst, M. (Eds). (2007). Tasks in action: Task-based language education from a classroom-based perspective. Newcastle: Cambridge Scholars Press.

Breen, M. (1987). Learner contributions to task design. In C. Candlin, \& D. Murphy (Eds.), Language learning tasks (pp. 23-46). Englewood Cliffs NJ: Prentice-Hall.

Bullough, R. V. (1997). Practicing theory and theorizing practice in teacher education. In J. Loughran, \& T. Russell (Eds.), Teaching about teaching (pp. 13-31). London, UK: Falmer Press.

Cameron, L. (1997). The task as a unit for teacher development. ELT Journal, 51(4), 345-351. http://dx.doi.org/10.1093/elt/51.4.345

Carless, D. (2003). Issues in teachers' reinterpretation of a task-based innovation in primary schools. TESOL Journal, 38(4), 639-662. http://dx.doi.org/10.2307/3588283

Chatman, E. A. (1992). The information world of retired women. Westport, CT: Greenwood Press.

Chuang, Y. Y. (2010). Implementing task-based language approach to teach and assess oral proficiency in the college EFL classroom. (NSC 99-2410-H-230-012) Taipei, Taiwan: National Science Council.

Clark, J., Scarino, A., \& Brownell, J. (1994). Improving the quality of learning: A framework for Target-Oriented Curriculum renewal. Hong Kong SAR, China: Instituteof Language in Education.

Creswell, J. W. (2009). Research design: Qualitative, quantitative, and mixed methods approach (3rd ed.). Thousand Oaks, CA: Sage Publications.

Eckerth, J., \& Siekmann, S. (2008). Task-based language learning and teaching: Theoretical, methodological, and pedagogical perspectives. Frankfurt: Peter Lang. 
Ellis, R. (2000). Task-based research and language pedagogy. Language Teaching Research, 4(3), 193-220. http://dx.doi.org/ 10.1177/136216880000400302

Ellis, R. (2003). Task-based language teaching. Oxford, UK: Oxford University Press.

Flick, U. (1998). An introduction to qualitative research. Thousand Oaks, CA: Sage Publications.

Gatbonton, E., \& Gu, G. (1994). Preparing and implementing a task-based ESL curriculum in an EFL setting: Implications for theory and practice. TESL Canada Journal, 11(2), 9-29. Retrieved from http://files.eric.ed.gov/fulltext/EJ493129.pdf

Hayes, D. (1995). In-service teacher development: Some principles. ELT Journal, 49(3), 252-261. http://dx.doi.org/10.1093/elt/49.3.252

Honeyfield, J. (1993). Responding to task difficulty. In M. Tickoo (Ed.), Simplification: Theory and practice (pp. 127-138). Singapore: Regional Language Center.

Jackson, D. O. (2012). Task-based language teacher education in an undergraduate program in Japan. In A. Shehadeh, \& C. A. Coombe (Eds), Task-based language teaching in foreign language contexts: Research and implementation (pp. 267-286). Amsterdam, the Netherlands: John Benjamins Publishing Company.

Jeon, I. J., \& Hahn, J. W. (2006). Exploring EFL teachers' perceptions of task-based language teaching: A case study of Korean secondary school classroom practice. Asian EFL Journal, 8(1), Article 8. Retrieved from http://www.asian-efl-journal.com/March_06_ijj.php

Kvale, S. (1996). Interviews: An introduction to qualitative research interviewing. Thousand Oaks, CA: Sage Publications.

Lantolf, J. P. (2000a). Second language learning as a mediated process. Language Teaching, 33(2), 79-96. http://dx.doi.org/10.1017/S0261444800015329

Lantolf, J. P. (2000b). Sociocultural theory and second language learning. Oxford, UK: Oxford University Press.

Lewis, M. (1994). Task-based second language teacher education programmes. Many Voices: A Journal of New Settlers and Multicultural Education Issues, 7, 10-12. Retrieved from http://www.voced.edu.au/content/ngv36418

Levelt, W. (1989). Speaking: from intention to articulation. Cambridge, UK: Cambridge University Press.

Littlewood, W. (2004). The task-based approach: Some questions and suggestions. ELT Journal, 58(4), 319-326. http://dx.doi.org/ 10.1093/elt/58.4.319

Long, M. (1985). A role for instruction in second language acquisition. In K. Hyltenstam, \& M. Pienemann (Eds.), Modelling and assessing second language Acquisition (pp. 77-99). Clevedon Avon: Multilingual Matters.

Lunenberg, M. L., Korthagen, F., \& Swennen, A. (2007). The teacher educator as a role model. Teaching and Teacher Education, 23(5), 586-601. http://dx.doi.org/10.1016/j.tate.2006.11.001

Mackey, A., \& Gass, S. (2006). Pushing the methodological boundaries in interactionresearch: An introduction to the special issue. Studies in Second Language Acquisition, 28(2), 169-178. http://dx.doi.org/10.1017/S02722631060086

McDonough, K., \& Chaikitmongkol, W. (2007). Teachers' and learners' reactions to a task-based EFL course in Thailand. TESOL Quarterly, 41(1), 107-132. http://dx.doi.org/ 10.1002/j.1545-7249.2007.tb00042.x

Merriam, S. B. (2009). Qualitative research: A guide to design and implementation. San Francisco, CA: Jossey-Bass.

Moser, J., Harris, J., \& Carle, J. (2012). Improving teacher talk through task-based approach. ELT Journal, 66(1), 81-88. http://dx.doi.org/10.1093/elt/ccr016

Nunan, D. (2004). Task-based language teaching. Cambridge, UK: Cambridge University Press.

Ogilvie, G., \& Dunn, W. (2010). Taking teacher education to task: Exploring the role of teacher education in promoting the utilization of task-based language teaching. Language Teaching Research, 14(2), 161-181. http://dx.doi.org/ 10.1177/1362168809353875

Oxford, R. (2006). Task-based language teaching and learning: An overview. The Asian EFL Journal Quarterly, 8(3), 94-121. Retrieved from http://www.idemployee.id.tue.nl/g.w.m.rauterberg/amme/oxford-2006.pdf 
Plews, J. L., \& Zhao, K. (2010). Tinking with tasks knows no bounds: ESL teachers' adaptation of task-based language teaching. TESOL Canada Journal, 28(1), 41-59. Retrieved from http://teslcanadajournal.ca/index.php/tes1/article/viewFile/1059/878

Richards, J., Platt, J., \& Weber, H. (1986). Longman Dictionary of Applied Linguistics. London, UK: Longman.

Ruys, I., Defruyt, S., Rots, I., \& Aelterman, A. (2013). Differentiated instruction in teacher education: A case study of congruent teaching. Teachers and Teaching: Theory and practice, 19(1), 93-107. http://dx.doi.org/10.1080/13540602.2013.744201

Samuda, V., \& Bygate, M. (2008). Tasks in second language learning. Basingstoke: Palgrave Macmillan.

Skehan, P. (1998). Task-based instruction. Annual Review of Applied Linguistics, 18, 268-286. Retrieved from http://faculty.ksu.edu.sa/yousif/3422/Task-based\%20instruction,\%20Skehan,\%202003.pdf

Swain, M. (2007). The impact of task-based professional development on teachers' practices and beliefs: A design research study. Journal of Mathematics Teacher Education, 10(4-6), 217-237. http://dx.doi.org/10.1007/s10857-007-9038-8

Swennen, A., Korthagen, F., \& Lunenberg, M. L. (2004). Congruent teaching by teacher educators. VELON Tijdschrift voor lerarenopleiders, 25(2), 17-18. Retrieved from http://www.velon.nl/tijdschrift_en_publicaties/tijdschrift_voor_lerarenopleiders/tijdschrift_voor_lerarenopl eiders_tijdschrift-publicaties-item/t/congruent_opleiden_door_lerarenopleiders

Swennen, J. M. H., Lunenberg, M. L., \& Korthagen, F. (2008). Preach what you teach! Teacher educators and congruent teaching. Teachers and Teaching: Theory and Practice, 14(6), 531-542. http://dx.doi.org/10.1080/13540600802571387

Van den Branden, K. (2006). Task-based language teaching: From theory to practice. Cambridge: Cambridge University Press.

Van den Branden, K. (2009). Mediation between predetermined order and chaos: The role of the teacher in task-based language education. International Journal of Applied Linguistics, 19(3), 264-285. http://dx.doi.org/10.1111/j.1473-4192.2009.00341.x

Van Patten, B. (1996). Input processing and grammar instruction in second languageacquisition. Norwood, NJ: Ablex.

Vygotsky, L. (1978). Mind in society. Cambridge, MA: Harvard University Press.

Yin, R. K. (2008). Case study research: Design and methods. Thousand Oaks, CA: Sage.

\section{Appendix}

\section{Class Evaluations}

1. What did you learn about TESOL issues from these tasks?

2. Which tasks did you like the most? Why?

3. Which tasks did you like the least? Why?

4. Which tasks helped you learn the most about TESOL issues? Why?

5. Which tasks helped you learn the least about TESOL issues? Why?

6. How did you feel about doing different tasks?

7. Which did you prefer: (1) complete the task on your own, (2) complete the task in a group, or (3) complete the task as a whole class? Why?

8. How did completing these tasks help you learn about TESOL issues and method?

9. Were the instructions on completing these tasks clearly given?

\section{Copyrights}

Copyright for this article is retained by the author(s), with first publication rights granted to the journal.

This is an open-access article distributed under the terms and conditions of the Creative Commons Attribution license (http://creativecommons.org/licenses/by/3.0/). 